\title{
Killing of $\alpha$-haemolytic and non-haemolytic Escherichia coli strains in human serum and polymorphonuclear leucocytes
}

\author{
L. SIEGFRIED*, H. PUZOVÁ, M. KMEŤOVÁ and A. KERESTEŠOVÁ
}

\author{
Department of Microbiology, Faculty of Medicine, University of P. J. Safárik, Srobárova 57, 04000 \\ Košice, Czechoslovakia
}

\begin{abstract}
Summary. The role of $\alpha$-haemolysin (AH) in the resistance of Escherichia coli strains, isolated from patients with extra-intestinal diseases or diarrhoea, to the bactericidal activity of human serum and intracellular killing in polymorphonuclear leucocytes (PMNL) was investigated in vitro. Sets of $\alpha$-haemolytic and non-haemolytic $E$. coli strains and sets of isogenic $E$. coli strains, which included wild-type $\alpha$-haemolytic strains and derived strains with a reduced production of $\mathrm{AH}$, were used. Compared with non-haemolytic strains, $\alpha$-haemolytic strains were significantly more resistant to the bactericidal activity of $10 \%$ and $100 \%$ human serum and to intracellular killing in PMNL. Higher resistance to serum killing and to intracellular killing in PMNL was also found in wild-type $\alpha$-haemolytic $E$. coli than in isogenic bacteria with reduced production of $\mathrm{AH}$. These results provide evidence that production of $\mathrm{AH}$ in $E$. coli strains counteracts both the bactericidal activity of serum and intracellular killing in PMNL.
\end{abstract}

\section{Introduction}

From studies in recent years it appears that Escherichia coli strains isolated from cases of intestinal and extra-intestinal diseases are endowed with certain traits considered of importance for virulence. These include production of bacterial adhesins, ${ }^{1}$ certain $\mathrm{O}$ group ${ }^{2}$ and $\mathrm{K}$ antigens, ${ }^{3}$ expression of the siderophore aerobactin, ${ }^{4}$ production of colicin $\mathrm{V},{ }^{5}$ production of thermolabile and thermostable enterotoxins, ${ }^{6}$ verocytotoxin, ${ }^{7}$ cytotoxic necrotising factor, ${ }^{8} \alpha$-haemolysin ${ }^{9}$ (AH) and resistance to the bactericidal activity of serum $^{10}$ and to phagocytosis. ${ }^{11}$

In E. coli, it has been shown that several properties of the bacterial cell-wall complex function as determinants of resistance to the bactericidal effect of serum. Rough phenotypes are, generally, more sensitive to serum killing than are smooth strains. ${ }^{12}$ Moreover, it has been shown that certain plasmids can increase the resistance of $E$. coli to serum killing, presumably via a mechanism that causes a modification in the bacterial surface. ${ }^{13}$ From several reports it is known that capsular antigens play an important role in virulence of bacteria, conferring serum resistance and inhibiting phagocytosis. ${ }^{14-16}$ Another factor influencing phagocytosis is $\mathrm{AH}$. Gadeberg and Blom ${ }^{17}$

Received 23 July 1991; accepted 29 Aug. 1991.

* Correspondence should be sent to: Dr L. Siegfried, Matuškova 6, 04011 Košice, Czechoslovakia. reported that $\mathrm{AH}$ may damage cells of the host immune system, i.e., human blood monocytes and polymorphonuclear leucocytes (PMNL). In our previous reports, ${ }^{18,19}$ we suggested that $\mathrm{AH}$ may contribute to the resistance of $E$. coli strains isolated from intestinal and extra-intestinal diseases to serum bactericidal effects and to phagocytosis. To establish if this is true, we have compared the response of groups of $\alpha$-haemolytic and non-haemolytic $E$. coli strains, and sets of isogenic strains differing in $\mathrm{AH}$ production, to the bactericidal activity of human serum and intracellular killing in PMNL.

\section{Materials and methods}

\section{Bacterial strains}

A total of 80 clinical isolates of $E$. coli was studied-43 $\alpha$-haemolytic and 37 non-haemolytic strains. They were isolated from faeces of infants with diarrhoea (51 isolates), or from extra-intestinal samples ( 29 isolates). Of these latter isolates, 13 were from pharyngeal exudate of infants with pharyngitis, eight from urine of infants with urinary tract infections and eight from mothers with vaginal discharge. The strains were serotyped with eight polyvalent and 52 monovalent $O$ antisera (Imuna). Non-haemolytic mutant strains were derived from $\alpha$-haemolytic $E$. coli strains by treatment with rifampicin. ${ }^{20}$ 


\section{Serum and $P M N L$}

Blood from one healthy donor was obtained by venepuncture and allowed to clot for $15 \mathrm{~min}$ at room temperature. After centrifugation $(1500 \mathrm{~g})$ the serum was removed, fractionated into small volumes and stored at $-70^{\circ} \mathrm{C}$ until needed.

PMNL for tests of intracellular killing of $E$. coli were obtained from fresh, unheparinised blood of healthy donors.

\section{Quantification of $\alpha$-haemolysin production}

The test was a modification of the method of Tabouret et al. ${ }^{21}$ An overnight culture of bacteria $(125 \mu \mathrm{l})$, grown in Todd-Hewitt Broth (Difco) containing $10 \mathrm{mM} \mathrm{CaCl}_{2}$, was inoculated into $5 \mathrm{ml}$ of the same medium and incubated in a waterbath at $37^{\circ} \mathrm{C}$ with agitation for $4 \mathrm{~h}$. Supernates were collected after centrifugation $\left(10000 \mathrm{~g}\right.$ for $10 \mathrm{~min}$ at $\left.4^{\circ} \mathrm{C}\right)$, adjusted to $\mathrm{pH} 7 \cdot 0-7 \cdot 4$ with $1 \mathrm{~N} \mathrm{NaOH}$ and assayed for haemolytic activity in polystyrene microtitration plates. Two-fold dilutions (in 100- $\mu$ l volumes) of culture supernate in


were made; $50 \mu \mathrm{l}$ of washed sheep erythrocytes $(1 \%$ suspension) was added to each dilution and the mixtures were incubated at $37^{\circ} \mathrm{C}$ for $2 \mathrm{~h}$ with occasional shaking. After incubation, $0.1 \mathrm{ml}$ of saline was added and unlysed erythrocytes were pelleted by centrifugation ( $1000 \mathrm{~g}$ for $2 \mathrm{~min}$ ). Determination of $50 \%$ haemolysis was based on counting of unlysed erythrocytes in a Bürker chamber. The number of haemolytic units (HU50/ml) was expressed as the dilution corresponding to $50 \%$ haemolysis.

\section{Serum bactericidal assay}

The assay was a slight modification of a method previously described. ${ }^{22}$ Overnight cultures of $E$. coli grown at $37^{\circ} \mathrm{C}$ on blood agar, were harvested. The cell suspensions were adjusted in Hanks's Balanced Salts Solution (HBSS) to contain $2.5 \times 10^{4} \mathrm{cfu} / \mathrm{ml}$. Microplates were employed for incubation of bacteria with serum. One well contained $0.05 \mathrm{ml}$ of $10 \%$ or $100 \%$ serum. The control well contained $0.05 \mathrm{ml}$ of HBSS instead of serum. The microplates were sealed with adhesive tape to prevent evaporation and placed on a roller (angle $45^{\circ}$ ) and rotated for $180 \mathrm{~min}$. Samples $(10 \mu \mathrm{l})$ were withdrawn after incubation for 60,120 and $180 \mathrm{~min}$ at $37^{\circ} \mathrm{C}$ and spread on blood agar plates. The plates were incubated for $18 \mathrm{~h}$ at $37^{\circ} \mathrm{C}$ and the viable count was determined. Susceptibility of bacteria to serum bactericidal activity was expressed as percentage of bacteria surviving after $180 \mathrm{~min}$ in relation to the original count of bacteria found at $0 \mathrm{~min}$ in the controls. Susceptibility of bacteria to serum was estimated by the Benge method. ${ }^{23}$ Strains were termed serum sensitive if the viable count dropped to $1 \%$ of the initial value and resistant if $>90 \%$ of organisms survived after $180 \mathrm{~min}$. Strains that gave results between these values were considered of intermediate sensitivity.

\section{Intracellular killing in PMNL}

The intracellular killing of bacteria by human PMNL was determined microscopically with a slightly modified acridine orange staining method. ${ }^{24}$ Fresh human blood $(0.2 \mathrm{ml})$ was placed on a sterile cover slip in a humidified plastic chamber and allowed to clot for $60 \mathrm{~min}$ at $37^{\circ} \mathrm{C}$. Coagulated blood was removed by rinsing the cover slips gently in warm $\left(37^{\circ} \mathrm{C}\right) \mathrm{HBSS}$. Bacteria pre-opsonised in $100 \%$ serum at $37^{\circ} \mathrm{C}$ for 15 min were placed on to the PMNL monolayer. After incubation for $60 \mathrm{~min}$, the cover slips were removed, air dried and stained with acridine orange $(1 \mathrm{mg} / \mathrm{ml})$ for $1 \mathrm{~min}$. In this assay, intracellular bacteria fluoresce green when viable and red if non-viable. The viability of organisms in a total of $100 \mathrm{PMNL}$ was estimated. The percentage killed was the percentage of intracellular organisms that were non-viable (red), i.e.,

$$
\begin{gathered}
\text { percent } \\
\text { killed }
\end{gathered}=\frac{\begin{array}{c}
\text { total number of non-viable } \\
\text { bacteria in } 100 \text { PMNL }
\end{array}}{\begin{array}{c}
\text { total number of } \\
\text { intracellular bacteria }
\end{array}} \times 100
$$

\section{Statistical analyses}

The $\chi^{2}$ test was used for statistical comparison of the proportion of serum resistant isolates in $\alpha$-haemolytic versus non-haemolytic $E$. coli, and of the relationship of $\mathrm{O}$ type with isolate origin, $\mathrm{AH}$ and serum resistance. Differences in intracellular killing ( $\alpha$-haemolytic versus non-haemolytic isolates) were estimated by Student's $t$ test (two-samples analysis). Statistical comparison of results in wild-type strains and isogenic derivatives was made by Student's paired $t$ test. Values of $\mathrm{p}<0.05$ were regarded as significant.

\section{Results}

\section{Association of $O$ type with isolate origin, $A H$ and serum resistance}

Of the $80 \mathrm{E}$. coli strains, 29 were from extraintestinal sources and 51 from faeces (table I); 60 strains were typable and belonged to $20 \mathrm{O}$ serogroups. Of the 20 non-typable strains, four $(13.8 \%)$ were from extra-intestinal sources and $16(31.4 \%)$ from faeces. Serogroup O6 was significantly more frequent among strains from extra-intestinal sources than among those from faeces $(24.1 \%$ versus $3.9 \%, p<0.01)$. A marked, but not statistically significant, difference was in the presence of serogroup $\mathrm{O} 55$ among isolates from faecal specimens compared to those from extra-intestinal sources $(23.5 \%$ versus $13.5 \%)$. Serogroup O26 was found with the same frequency among strains isolated 
Table I. Association of $E$. coli $\mathrm{O}$ serogroups with isolate origin, $\alpha$-haemolysin production and serum resistance

\begin{tabular}{ccccc}
\hline \multirow{2}{*}{ Serogroup } & Source of & \multicolumn{3}{c}{ Number of strains } \\
\cline { 3 - 5 } & isolates & Total & AH & R \\
\hline 02 & E & 1 & 1 & 1 \\
& D & 0 & 0 & 0 \\
06 & E & 7 & 7 & 5 \\
& D & 2 & 1 & 1 \\
& E & 2 & 1 & 1 \\
026 & D & 1 & 0 & 0 \\
& E & 4 & 2 & 2 \\
055 & D & 7 & 4 & 2 \\
& E & 4 & 4 & 3 \\
& D & 12 & 8 & 7 \\
& E & 1 & 1 & 1 \\
Other O-antigenic type & D & 1 & 0 & 0 \\
& E & 6 & 3 & 2 \\
Non-typable isolates & D & 12 & 4 & 4 \\
& E & 4 & 3 & 3 \\
& D & 16 & 5 & 2 \\
& & & & \\
\hline
\end{tabular}

E, strains isolated from extra-intestinal sources; $D$, strains isolated from faeces in diarrhoeal diseases; $\mathrm{AH}, \alpha$-haemolysin production; $R$, serum resistance.

from both sources (13.7\%). Production of AH was more frequent in serogroups $\mathrm{O} 6, \mathrm{O} 26$ and $\mathrm{O} 55$ than in other O-groups and non-typable isolates (72.2\% versus $40.9 \%, \mathrm{p}<0.01)$. Serum resistance was more frequent in strains of serogroup $\mathrm{O6}$ and $\mathrm{O55}$ than in strains of serogroup O26, other O-groups, and nontypable strains $(64 \%$ versus $32.7 \%, \mathrm{p}<0.05)$.

\section{Bactericidal activity of serum and PMNL against $\alpha$ - haemolytic and non-haemolytic E. coli strains}

Results of killing of $\alpha$-haemolytic and non-haemolytic $E$. coli in serum and PMNL are shown in table II. There were differences between the response of isolates to $10 \%$ and $100 \%$ serum. A greater proportion of $\alpha$-haemolytic than non-haemolytic strains was serum resistant. When $10 \%$ serum was employed all the $\alpha$-haemolytic isolates were resistant to serum killing, but only $84 \%$ of non-haemolytic strains $\left(\chi^{2}=\right.$ $7.54, \mathrm{p}<0.01$ ). When $100 \%$ serum was used, $63 \%$ of the $\alpha$-haemolytic strains were resistant compared to $22 \%$ of the non-haemolytic strains $\left(\chi^{2}=13 \cdot 69\right.$, $\mathrm{p}<0.01)$.

\section{Response of wild-type $\alpha$-haemolytic $E$. coli and their non-haemolytic derivatives to killing by serum and $P M N L$}

After treatment with $100 \%$ serum for 180 min, the survival of non-haemolytic derivatives was markedly depressed compared with wild-type $\alpha$-haemolytic isolates $(t=4.62, p<0.01)$. Similarly, in wild-type $\alpha$ haemolytic isolates compared to their non-haemolytic derivatives there was significantly higher resistance to intracellular killing in PMNL $(t=4.88, p<0.01)$.

Table II. Susceptibility of $\alpha$-haemolytic and non-haemolytic $E$. coli strains to the bactericidal activity of serum and intracellular killing in PMNL

\begin{tabular}{|c|c|c|c|c|c|c|c|c|}
\hline \multirow{3}{*}{$\begin{array}{l}\text { Haemolytic status } \\
\text { (number of } \\
\text { strains) }\end{array}$} & \multicolumn{6}{|c|}{$\begin{array}{l}\text { In serum, number of } \\
\text { strains that were }\end{array}$} & \multicolumn{2}{|c|}{$\begin{array}{l}\text { Percentage of } \\
\text { intracellular } \\
\text { killing in PMNL }\end{array}$} \\
\hline & \multicolumn{2}{|c|}{$\mathbf{R}$} & \multicolumn{2}{|c|}{ I } & \multicolumn{2}{|c|}{$\mathbf{S}$} & & \\
\hline & $10 \%$ & $100 \%$ & $10 \%$ & $100 \%$ & $10 \%$ & $100 \%$ & & \\
\hline $\begin{array}{l}\mathrm{AH} \\
(43) \\
\mathrm{NH} \\
(37)\end{array}$ & $\begin{array}{c}43 \\
\mathrm{p}<0.01 \\
31\end{array}$ & $\begin{array}{c}27 \\
\mathrm{p}<0.01 \\
8\end{array}$ & 0 & 14 & 0 & 2 & $\begin{array}{l}79.5(8.6) \\
\mathrm{p}<0.01 \\
84.4(6.9)\end{array}$ & $\begin{array}{r}54-92 \\
64-94\end{array}$ \\
\hline
\end{tabular}

AH, $\alpha$-haemolytic; NH, non-haemolytic; R, serum resistant; I, intermediate sensitivity; S, serum sensitive.

Table III. Characteristics of four pairs of isogenic $E$. coli strains

\begin{tabular}{lcccl}
\hline $\begin{array}{c}\text { Strains } \\
\text { nos. }\end{array}$ & $\begin{array}{c}\text { Percentage survival } \\
\text { in serum }\end{array}$ & $\begin{array}{c}\text { Percentage intra- } \\
\text { cellular killing }\end{array}$ & $\begin{array}{c}\alpha \text {-haemolysin } \\
\text { production (HU50/ml) }\end{array}$ & Origin \\
\hline $688 \mathrm{AH}^{+}$ & 220 & 71 & 512 & Diarrhoea \\
$688 \mathrm{AH}^{-}$ & 0 & 83 & $<2$ & Mut(Rif)* \\
$694 \mathrm{AH}^{+}$ & 197 & 63.5 & 256 & Diarrhoea \\
$694 \mathrm{AH}^{-}$ & 3 & 74 & $<2$ & Mut(Rif) \\
$698 \mathrm{AH}^{+}$ & 124 & 72.5 & 128 & Diarrhoea \\
$698 \mathrm{AH}^{-}$ & 1 & 80 & $<2$ & Mut(Rif) \\
$699 \mathrm{AH}^{+}$ & 96 & $90 \cdot 5$ & 8 & Diarroea \\
$699 \mathrm{AH}^{-}$ & 2 & & $<2$ & Mut(Rif) \\
\hline
\end{tabular}

* Mutant strain selected by rifampicin. 


\section{Discussion}

In this paper serum resistance and intracellular killing of $\alpha$-haemolytic and non-haemolytic $E$. coli strains were compared. Not much has been known about the role of $\mathrm{AH}$ in resistance of $E$. coli to the bactericidal activity of human serum and intracellular killing in PMNL. As previously described, production of $\mathrm{AH}$ is associated with certain $\mathrm{O}$ antigens ${ }^{25}$ and it is largely found in $E$. coli causing extra-intestinal infections, ${ }^{26}$ rarely in isolates from healthy people. ${ }^{8}$ In earlier reports, Knipschildt ${ }^{27}$ and Kauffman ${ }^{28}$ demonstrated that haemolytic $E$. coli strains belonged mainly to $\mathrm{O}$ groups 2, 4 and 6 . Hughes et al. ${ }^{25}$ found $50 \%$ of $E$. coli strains of groups $\mathrm{O} 18$ and $\mathrm{O} 75$ were haemolytic. Moreover, they suggested an association of $\mathrm{AH}$ production and serum resistance with serogroups $\mathrm{O6}$, $\mathrm{O} 18$ and $\mathrm{O} 75$. Our results showed that $\mathrm{AH}$ production and serum resistance were associated with O groups 6 and 55; the former dominated in extra-intestinal isolates and the latter in faecal isolates.

Several reports have shown that there are various virulence determinants at the cell-wall surface that may play certain roles in the resistance of $E$. coli strains to the bactericidal activity of human serum. ${ }^{15,29,30} \mathrm{Our}$ results indicate that $\mathrm{AH}$ could be another factor increasing the serum resistance of $E$. coli. This suggestion arises not only from the significantly higher serum resistance found in $\alpha$-haemolytic isolates than in nonhaemolytic ones, but mainly from the significantly higher serum resistance found in wild-type $\alpha$-haemolytic isolates than in isogenic derivatives with reduced production of $\mathrm{AH}$. Hughes et $a .^{25}$ have suggested a possible role of $\mathrm{AH}$ in serum resistance.

Several recent reports have shown that treatment of phagocytes with $\mathrm{AH}$ reduces their ability to respond to chemotactic stimuli, to phagocytose bacteria and to kill them. ${ }^{31,32}$ Moreover, Gadeberg and Larsen $^{33}$ found that $\alpha$-haemolytic $E$. coli were toxic to

\section{References}

1. Klemm P. Fimbrial adhesins of Escherichia coli. Rev Infect Dis 1985; $7: 321-340$

2. Ørskov F, Ørskov I. Escherichia coli $\mathrm{O}: \mathrm{H}$ serotypes isolated from human blood. Prevalence of the $\mathrm{Kl}$ antigen with technical details of $\mathrm{O}$ and $\mathrm{H}$ antigenic determination. APMIS Sect B 1975; 83: 595-600.

3. Evans DJ, Evans DG, Höhne $\mathrm{C}$ et al. Hemolysin and $\mathrm{K}$ antigens in relation to serotype and hemagglutination type of Escherichia coli isolated from extraintestinal infections. $J$ Clin Microbiol 1981; 13: 171-178.

4. Johnson JR, Moseley SL, Roberts PL, Stamm WE. Aerobactin and other virulence factor genes among strains of Escherichia coli causing urosepsis: association with patient characteristics. Infect Immun 1988; 56: 405-412.

5. Minshew BH, Jorgensen J. Counts GW, Falkov S. Association of hemolysin production, hemagglutination of human erythrocytes, and virulence for chicken embryos of extraintestinal Escherichia coli isolates. Infect Immun 1978; 20: $50-54$.

6. Levine MM. Escherichia coli that cause diarrhoea: enterotoxigenic, enteropathogenic, enteroinvasive, enterohemorrhagic, and enteroadherent. $J$ Infect Dis 1987; 155: $377-389$. phagocytes and this cytotoxic effect corresponded with titres of AH production. However, experiments with pre-treated cells only incompletely indicate the significance of $\mathrm{AH}$ for the outcome of $E$. coli interaction with phagocytes. Results of this study support their findings; we found a lower level of killing of $\alpha$ haemolytic E. coli strains in PMNL than of nonhaemolytic ones. However, there were considerable differences in intracellular killing among isolates examined. This could be ascribed to different levels of AH produced by particular isolates (unpublished observation). To distinguish a role of $\mathrm{AH}$ in intracellular killing, four sets of isogenic strains differing in $\mathrm{AH}$ production were used. The results obtained with these strains clearly demonstrate that $\alpha$-haemolytic $E$. coli were killed to a lesser extent than isogenic strains with reduced production of $\mathrm{AH}$. These results support those of Gadeberg et $a l^{34}$ who also found less intracellular killing of wild-type $\alpha$-haemolytic $E$. coli than of their non-haemolytic derivatives.

Taking into account the results obtained in this study and those previously reported, ${ }^{25,24}$ we consider that $\mathrm{AH}$ contributes not only to the resistance of $E$. coli to intracellular killing, but also to resistance to the bactericidal activity of serum. The mechanism of increased serum resistance by $\mathrm{AH}$ production could be explained by the finding of Bhakdi et al..$^{35}$ who have suggested that serum albumin, lipoproteins and other unidentified plasma factors are involved in neutralising $\mathrm{AH}$. Serum components involved in bacterial killing may be neutralised by interaction with $\mathrm{AH}$ thus leading to some failure of killing. Moreover, recent reports of Milford and Taylor ${ }^{36}$ and Caprioli et al.$^{8,37}$ raise the question of possible effects of extracellular products of $E$. coli other than $\mathrm{AH}$, e.g., verocytotoxin and cytotoxic necrotising factor closely associated with $\mathrm{AH}$ production, on phagocyte function. Further investigations are needed to elucidate this.

7. Karmali MA. Infection by verocytotoxin-producing Escherichia coli. Clin Microbiol Rev 1989; 2: 15-38.

8. Caprioli A, Falbo V, Ruggeri FM et al. Cytotoxic necrotizing factor production by hemolytic strains of Escherichia coli causing extraintestinal infections. J Clin Microbiol 1987; 25: $146-149$.

9. Cavalieri SJ, Bohach GA, Snyder IS. Escherichia coli $\alpha$ hemolysin. Characteristics and probable role in pathogenicity. Microbiol Rev 1984; 48: 326-343.

10. Taylor BW. Bactericidal and bacteriolytic activity of serum against gram-negative bacteria. Microbiol Rev 1983; 47 46-83.

11. Ørskov I, Ørskov F. Escherichia coli in extra-intestinal infections. J Hyg 1985; 95 : 551-575.

12. Reynolds BL, Pruul H. Protective role of smooth lipopolysac-charide in the serum bactericidal reaction. Infect Immun $1971 ; 4$ : 764-771.

13. Moll A, Manning PA, Timmis KN. Plasmid-determined resistance to serum bactericidal activity: a major outer membrane protein, the tra $T$ gene product, is responsible for plasmid-specified serum resistance in Escherichia coli. Infect Immun 1980; 28: 359-367.

14. Horwitz MA, Silverstein SC. Influence of the Escherichia coli capsule on complement fixation and on phagocytosis and killing by human phagocytes. J Clin Invest $1980 ; 65: 82-94$. 
15. Roberts IS, Saunders FK, Boulnois GJ. Bacterial capsules and interactions with complement and phagocytes. Biochem Soc Trans 1989; 17: 462-464

16. Leying H, Suerbaum S. Kroll H-P, Stahl D, Opferkuch W. The capsular polysaccharide is a major determinant of serum resistance in K-1-positive blood culture isolates of Escherichia coli. Infect Immun 1990; 58: 222-227.

17. Gadeberg OV, Blom J. Morphological study of the in vitro cytotoxic effect of $\alpha$-hemolytic $E$. coli bacteria and culture supernatants on human blood granulocytes and monocytes. APMIS Sect B 1986; 94: 75-83.

18. Siegfried L, Puzová H, Hlaučová J, Durovičová J. Evaluation of phagocytosis of alpha-hemolytic strains of Escherichia coli using the fluorescence method. Czek Epidemiol Mikrobiol Immunol 1989; 38: 204-208.

19. Siegfried L, Puzová H, Hlaučová J, Ďurovičová J, Kročková J, Ebert $\mathrm{HH}$. Killing of seroresistant plasmid bearing $E$. coli strains in polymorphonuclear leukocytes. Bratisl Lek Listy 1990; 91 : 292-297.

20. Mitchell I de G, Kenworthy R. Attempted elimination of plasmid-determined hemolysin, $\mathrm{K} 88$ antigen and enterotoxin from Escherichia coli pathogenic for pigs. $J$ Appl Bacteriol 1977; 42: 207-212.

21. Tabouret M, De Rycke J, Audurier A, Poutrel B. Pathogenicity of Listeria monocytogenes isolates in immunocompromised mice in relation to listeriolysin production. $J$ Med Microbiol 1991; 34: 13-18.

22. Miler I, Vondráček J, Hromádková L. The bactericidal activity of sera of healthy neonates and of newborns with hyperbilirubinaemia to Escherichia coli. Folia Microbiol 1979; 24: $143-152$.

23. Benge GR. Bactericidal activity of human serum against strains of Klebsiella from different sources. J Med Microbiol 1988; 27: $11-15$.

24. Pantazis CG, Kniker WT. Assessment of blood leukocyte microbial killing by using a new fluorochrome microassay. RES 1979; 26: 155-170.

25. Hughes C, Phillips R, Roberts AP. Serum resistance among Escherichia coli strains causing urinary tract infection in relation to $O$ type and the carriage of hemolysin, colicin, and antibiotic resistance determinants. Infect Immun 1982; 35: $270-275$.
26. Hughes C, Hacker J, Roberts AP, Goebel W. Hemolysin production as a virulence marker in symptomatic and asymptomatic urinary tract infections caused by Escherichia coli. Infect Immun 1983; 39: 546-551.

27. Knipschildt HE. Undersogelser over Coligruppens Serologi. Copenhagen, Nyt Nordisk Forlag, Arnold Busck. 1945 $1-156$.

28. Kauffmann F. The serology of the coli group. J Immunol 1947 ; 57: 71-100.

29. Timmis KN, Boulnois GJ, Bitter-Suermann D, Cabello FC. Surface components of Escherichia coli that mediate resistance to the bactericidal activities of serum and phagocytes. Curr Top Microbiol Immunol 1985; 118: 197-218.

30. Stawski G, Nielsen L, Ørskov F, Ørskov I. Serum sensitivity of a diversity of Escherichia coli antigenic reference strains. Correlation with an LPS variation phenomenon. APMIS $1990 ; 98: 828-838$.

31. Cavalieri SJ, Snyder IS. Effect of Escherichia coli alphahemolysin on human peripheral leukocyte function in vitro. Infect Immun 1982; 37: 966-974.

32. Pruett TL, Cheoweth DE, Fiegel VD, Nelson RD, Simmons RL. Escherichia coli and human neutrophils. Arch Surg $1985 ; 120$ : 212-216.

33. Gadeberg OV, Larsen SO. In vitro cytotoxic effect of $\alpha$ hemolytic Escherichia coli on human blood granulocytes. Correlation with size of $\alpha$-hemolysin production. APMIS $1988 ; 96: 337-341$

34. Gadeberg OV, Hacker J, Ørskov I. Role of $\alpha$-hemolysin for the in vitro phagocytosis and intracellular killing of Escherichia coli. Zentralbl Bakteriol 1989; 271 : 205-213.

35. Bhakdi S, Greulich S, Muhly $M$ et al. Potent leukocidal action of Escherichia coli hemolysin mediated by permeabilization of target cell membranes. J Exp Med 1989; 169: 737-754.

36. Milford DV, Taylor CM. New insights into the haemolytic uremic syndromes. Arch Dis Child 1990; 65: 713-715.

37. Caprioli A, Falbo V, Ruggeri FM, Minelli F, Ørskov I, Donelli G. Relationship between cytotoxic necrotizing factor production and serotype in hemolytic Escherichia coli. $J$ Clin Microbiol 1989; 27: 758-761. 